\title{
Óscar Cornago \\ De las organizaciones a las multitudes: pensar lo social más allá del Estado
}

\begin{abstract}
La sociabilidad es lo real; pero el ideal es la soledad, que es también la verdad profunda de nuestra naturaleza: ésta es la primera gran versión de la concepción individualista que subyace a nuestras representaciones de la vida humana (Tzvetan Todorov 1995: 19).
\end{abstract}

Los seres humanos son seres coexistentes que la mayoría de las veces no saben realmente hablar de los motivos de su coexistencia. ¿Qué es exactamente la coexistencia? Si nadie me lo pregunta, lo sé, si he de explicárselo a alguien que pregunta, no lo sé (Peter Sloterdijk 2006: 202).

La necesidad de compañía humana es instintiva (Rodrigo García 2008).

El auge del individualismo al mismo tiempo que la creciente falta de credibilidad de las formas de organización social consolidadas en los dos últimos siglos, en paralelo al cuestionamiento de los modelos políticos construidos sobre ellas, ha abierto un amplio panorama de reconsideración del fenómeno de lo social, de volver a pensar la necesidad de agrupación en la que viven los individuos y las motivaciones para llevar a cabo estas agrupaciones. La revisión que hace Todorov (1995) en su ensayo La vida en común del prejuicio antisocial en la tradición occidental puede servir de indicio de este estadio de llegada al que ha conducido la discusión de un modelo político basado en los EstadosNación. La repercusión de lo macropolítico en los espacios más inmediatos de sociabilidad, o dicho de otro modo: de los espacios públicos en el ámbito privado, ha obligado a replantear una situación aceptada de forma tan natural como la coexistencia entre sujetos.

A comienzo de los años ochenta, Alain Badiou, reflexionando sobre el espacio que le quedaba al pensamiento político en un momento en el que las ideologías de izquierdas perdían protagonismo, afirma que la historia política del siglo XX había sido básicamente la historia del marxismo, o -si se prefiere- del antimarxismo, un modelo de organización basado en la idea de emancipación de las clases dominadas. La revolución rusa, primero, las luchas campesinas y los frentes de liberación nacional, después, y finalmente los movimientos estu- 
diantiles y obreros de los años sesenta y setenta, son algunos de los pagarés -retomando la imagen de Badiou- que el marxismo libró contra la Historia para seguir teniendo crédito. Este crédito se agotó y ahí comienza la época de las posdictaduras; una época que, teniendo en cuenta que estas dictaduras se plantearon en oposición a su alternativa democrática, sería también la época de las posdemocracias. Karl Löwith, como recuerda Agamben (1998: 153), ya apuntó la paradójica relación de continuidad entre democracias y totalitarismos. Dicho crédito histórico no es, por tanto, solo el que pudo llegar a tener el marxismo como concreción de una ideología, sino igualmente el crédito que le quedaba a su otra cara política, una historia ligada a la idea de Estado y Nación, soberanía y emancipación, y como parte de este horizonte, al mismo proyecto literario que lo acompañó.

Carl Schmitt, uno de los defensores del nacionalsocialismo alemán, escribe con cierta nostalgia ya en los años sesenta que "[1]a época de la estatalidad está llegando a su fin" y que "[e]1 Estado como modelo de unidad política, el Estado como titular del más extraordinario de todos los monopolios, el monopolio de la decisión política, está por ser destronado" - cita recogida por Agamben (1998: 45) en su estudio sobre la configuración del poder soberano-. No es difícil sospechar que detrás de esta añoranza del "más extraordinario de todos los monopolios" no se esconde únicamente el Estado democrático, sino también y sobre todo -como nos hace ver Todorov (1993: 142)los Estados totalitarios, la realización histórica extrema de este proyecto político construido en torno a la idea del Estado y soberanía nacional.

La crisis de estos proyectos nacionales no implica únicamente la crisis de una forma de organización administrativa y económica, sino también y en primer lugar la de un complejo entramado de valores culturales y políticos que lo sostenían, ligadas a la negociación entre lo público y lo privado, entre individuo y colectivo. A través del Estado no solo se pensaba una forma de administración del espacio público, sino también la propia subjetividad enfrentada a este espacio. La realización de la idea de Nación en los Estados socialistas deja ver con claridad en qué medida este proyecto tuvo en la idea de pueblo uno de sus motores y piedra angular. La necesidad de asentar teóricamente la soberanía nacional sobre este pueblo que antes de ser pueblo fue una multitud informe, se convierte en una condición urgente para seguir 
manteniendo un sistema de poder. El poder - soberano- ya no se justificaba desde arriba, por la gracia de Dios, sino desde abajo, por la participación de esas multitudes convertidas en pueblo trabajador y soberano, generadas por un nuevo sistema económico.

Estas masas de obreros, mineros, operadores fabriles, a los que dio lugar la revolución industrial a lo largo del siglo XIX, fueron una multitud antes que clase obrera, una multitud no organizada de gente, de cuerpos desharrapados, de fuerza de trabajo congregada en torno a las fábricas y más tarde a las grandes ciudades. Esta multitud en algunos momentos reacciona, convirtiéndose en una fuerza social, de potencia pasa a ser acto, es entonces cuando -siguiendo a Badiou (2007)- surge un acontecimiento, algo sucede, una disfunción, una ruptura en el régimen de lo Uno, que es el régimen de la representación -y la representación es sobre todo la representación literaria de la Historia-. Éste es el desencadenante, según el pensador francés, del hecho político, su realidad primera, el acontecimiento prepolítico, el momento de la presentación.

En la medida en que los enunciados políticos dejan de responder a estos acontecimientos producidos por las masas, la política se retira de la realidad, y queda como el pensamiento de una ausencia, un imposible. Es así como se llega al momento de las posdictaduras, en el que esas

categorías fundadoras entre las que se escogía -derecha e izquierda, movimiento obrero y patronal, nacionalismo e internacionalismo, capitalismo y socialismo, socialismo y comunismo, libertad y autoridad- [son] cada vez más inoperantes,

al perder poco a poco su

capacidad de designar algo más que el retraso de los profesionales, el desheredamiento de los actores (Badiou 2007: 7).

No es solo Anderson (1993) quien llama la atención sobre el fiel aliado que el Estado encontró en el proyecto literario de la modernidad. Esas "comunidades imaginadas", con las que el autor inglés identifica los nacionalismos, no hubieran sido posibles sin la ayuda del capitalismo editorial. Pero incumplida la promesa del sueño humanista, se deja ver una vez más el declive del mito literario de Occidente, el mito de la palabra y la cultura literaria como contribución también a ese mismo proyecto de progreso y emancipación de los pueblos. Desde 
entonces, igual que dice Adorno (1975: 11) para la filosofía, que al fin y al cabo está en el nacimiento del mito de la escritura en Occidente, la filosofía -pero podríamos poner en su lugar la literatura- se ve obligada a criticarse sin consideraciones.

Más recientemente, y no sin un abierto afán de polémica, es Sloterdijk (2000) quien en las Normas para el parque humano, a modo de respuesta a la Carta de descargo que Heidegger escribe después de la II Guerra Mundial, retoma la discusión sobre los humanismos del siglo XX, poniendo de manifiesto su relación histórica con la comunicación escrita.

Allí donde el humanismo [...] se volvió pragmático y programático -dice el filósofo alemán-, como en los siglos XIX y XX con las ideologías liceístas de los Estados nacionales burgueses, el ejemplo de la sociedad literaria se amplió hasta convertirse en la norma para la sociedad política (Sloterdijk 2000: 25).

Si descendemos ahora a un nivel de análisis más concreto de las vinculaciones entre Estado y escritura, entre Nación y literatura, en $L a$ saga de los Marx, novela de Juan Goytisolo escrita a raíz de esa fecha simbólica de la caída del Muro de Berlín, encontramos una reflexión sobre el lugar desde el que llevar adelante un posible diálogo con el marxismo - o si preferimos con la Historia política de Occidente-; desde qué presente, histórico o literario, sería posible seguir actualizando el pasado político, la historia de Marx y su doctrina, que a la luz de las transformaciones sufridas por el concepto de "historia", no es solo su historia pública, sino también su historia privada, personal y familiar -como se hace ver en la novela-, y en paralelo a ésta, la propia historia literaria contenida en la herencia cultural de la que se tiene que hacer cargo el narrador, al que un afamado editor le ha encargado una biografía de los Marx que ha de servir de base para una exitosa serie de televisión sobre las aventuras y desventuras del autor de $E l$ capital.

La reflexión en ese tiempo del después de se despliega a varios niveles, político y literario, público y privado, colectivo y personal. Goytisolo mezcla espacios y tiempos, pasados y presentes, situando al fundador del marxismo -en un giro no carente de cierta crueldad- en la Europa de finales del siglo XX, como testigo privilegiado de la caída de esos Estados construidos a partir de su doctrina. La Historia le pide cuentas a su creador; los obreros, convertidos nuevamente en esa ma- 
sa informe de gente sin trabajo, miran cara a cara al detractor del capitalismo; por su parte, el editor y productor de la teleserie le pide cuentas también al narrador por el desaguisado que finalmente le entrega como novela, que se abre con esas masas de ex-obreros, los trabajadores liberados de la opresión del capital, tratando de huir del paraíso marxista.

Frente a las costas de una playa privada en Italia, donde se apretujan sus selectos socios para disfrutar de las bondades del verano, comienza a desembarcar de un ferry fantasmal un cargamento humano no menos fantasmal- que se precipita hacia la costa. Son emigrantes albaneses, una multitud informe de cuerpos desnutridos y sudorosos,

cuerpos y cuerpos chupados -se dice en el texto-, quemados y agrietados por el sol, de mirada ciega y órbitas hundidas, movimientos de animales salvajes y acorralados, sin resignarse aún a lo inevitable, a la inflexible ley que los excluía (Goytisolo 1993: 22),

son los "desertores del paraíso" (Goytisolo 1993: 21), como le espeta con despiadada ironía la hija de Marx a su padre mientras que, desde su piso en Londres, miran las imágenes que pasan por televisión.

La presencia física, acentuada por la condición masiva de los excluidos, de aquellos que no tienen derechos, deja ver los límites sobre los que se construye el denominado Estado de derecho. La condición extrema en la que llegan estas personas hace más patente que aquello que se está excluyendo es la propia vida en su sentido más básico.

La atracción de Goytisolo por las multitudes está presente en todo su mundo literario. Si en sus primeras novelas eran los refugiados que huían de las tropas nacionalistas en la Guerra Civil Española, luego se irán transformando, multiplicando y confundiendo con tantas otras multitudes perseguidas, grupos de seres humanos en movimiento tratando de sobrevivir a lo largo de los siglos, los parias de la historia en una espiral de metamorfosis, la chusma tratando de resistir a los embates de la historia, en un constante devenir animal, no-histórico, débiles, negros, no cristianos, parias.

La evolución literaria de Juan Goytisolo es un buen ejemplo para reflexionar sobre el paso de una producción bajo una sólida dictadura militar, como fue el Franquismo, a un estilo de madurez construido como respuesta explícita a los retos de un capitalismo global en el que el Estado español no tuvo dificultad en insertarse. La época de las posdictaduras, en la que los regímenes militares han sido sustituidos 
con asombrosa fluidez por regímenes democráticos, no le ha dejado de proporcionar ejemplos de estas multitudes errantes que tanto le han fascinado. En esta Europa del bienestar, que ha visto desaparecer los uniformes como cara reconocible del poder, siguen ocurriendo acontecimientos que irrumpen en el régimen de lo Uno al que se refiere Badiou, que desbordan las posibilidades de la representación política, como aquellas masas de obreros que irrumpieron en el horizonte histórico del siglo XIX, convirtiéndose en una fuerza social, o como los millones de desplazados que los regímenes políticos del siglo XX y XXI han tratado de aislar en campos de concentración; son los límites del mito de las democracias y los Estados-soberanos. En una sociedad donde todo parece estar ya previsto, programado (o al menos parecía, hasta hace unos años), las multitudes sin nombre siguen saltando a escena, desnudas, para recordarle a la política aquello que se le escapa, la posibilidad de la propia política en la fisura de lo irrepresentable, de lo que tendría que dar cuenta y se le resiste.

En ese "excedente de energía de las muchedumbres" encontró Goytisolo (1991: 90) un irresistible atractivo, el atractivo por un fenómeno humano donde la vida, en bruto, parece hacerse visible, moviéndose a un compás propio que crece desde dentro. Principio de creación y principio de destrucción parecen ir de la mano, no sólo del proyecto estético y ético de Goytisolo, sino también de la dinámica de las masas como potencia social, pues su "impulso de destrucción" -concluye el narrador de La saga de los Marx (Goytisolo 1993: 52)no "era a fin de cuentas su instinto creador más profundo?"

En unos términos comparables se refiere Negri en un libro de conversaciones bajo el provocativo título de Goodbye Mr. Socialism a las masas como una energía social viva, porque

donde hay masa -afirma Negri (2007: 31)- hay energía, y que esto es fundamental en la concepción de lo común, que nunca es un depósito, sino precisamente una energía y una potencia, es capacidad de expresión,

aunque no se esté refiriendo aquí a las masas de desplazados, sino a esas otras que de modo no controlado se condensan e irrumpen en los espacios urbanos, otro de los lugares que el autor de Después de la batalla ha recorrido con afán de entomólogo.

El activista italiano y pensador político explica la evolución del capitalismo industrial como un fenómeno guiado por la tendencia 
expansionista de un capital que ya no podía seguir creciendo dentro de las fronteras de los Estados-Nación. El nuevo orden económico necesita funcionar a escala mundial; el capital se tiene que mover con mayor libertad. Esto conduce a la crisis de los Estados-Nación como actores principales del orden internacional, lo cual no quiere decir que no sigan existiendo, quizá ya como figurantes de segundo orden, como le va a ocurrir a la propia literatura, no por azar unida al destino de los Estados nacionales. Los Estados que llegan a este momento en una situación de debilidad serán los que sufran de manera más drástica los efectos de este nuevo orden mundial, como explican Negri y Cocco refiriéndose a los Estados latinoamericanos:

La perspectiva del desarrollo pierde su horizonte nacional y por consiguiente sus ilusorios atajos tecnocrático-autoritarios, así como las ambiguas alianzas interclasistas (en la tradición de los partidos comunistas, entre clase obrera y burguesía nacional contra las oligarquías feudales y los intereses imperialistas y, luego, entre el Estado desarrollista autoritario y las grandes empresas multinacionales extranjeras) (Negri/Cocco 2006: 49).

El periodo de auge de estos Estados lo sitúan Negri y Cocco entre los años treinta y los setenta, coincidiendo en el caso de Latinoamérica con los gobiernos populistas de tendencias totalitarias, que fueron a su vez sustituidos por las dictaduras militares. Al concepto de "pueblo", promovido por estos gobiernos, le seguirá el de "nación". "Necesitamos menos Estado y más nación", clamará algún militar argentino ya en los sesenta (Negri/Cocco 2006: 46). Bajo esta consigna se consolidará la política del desarrollismo que llevará al endeudamiento de una gran parte de los países en vías de desarrollo. "Nación" y "Estado" se convierten en dos conceptos claves, como las dos caras de una realidad atravesadas por tendencias diversas y hasta contradictorias. Tras el auge de las políticas estatales, el neoliberalismo de los ochenta inaugura un período de libre intercambio al amparo de organizaciones supranacionales como el Fondo Monetario Internacional. A esta necesidad de apertura de los flujos económicos ya no contribuyen los regímenes dictatoriales, ni los pueblos, ni las naciones. Es entonces cuando Margaret Thatcher dirá aquello de que "[1]a sociedad ha muerto. Sólo existen los individuos" (Bauman 2005: 35), inaugurando un nuevo capítulo de la modernidad en el que una vez más, como ya 
hiciera notar Foucault (1997), la cultura del individualismo y los mecanismos de un poder totalitario van a ir de la mano.

La disolución del tejido estatal vuelve a hacer visible a las multitudes por las calles de las grandes ciudades. El caso de Argentina, donde una multitud, no ya de desharrapados, sino de gente de clase media que sale de forma espontánea al ruido de las cacerolas para reclamar sus ahorros gritando "Que se vayan todos", constituye una escena paradójica: los sirvientes del Estado rebelándose contra el padre político. La pregunta queda en el aire: ¿cómo seguir pensando la sociedad sin el paraguas del Estado? "Tras el desfondamiento varía la condición del Estado" - dice Lewkowicz (2004: 10) al comienzo de un conjunto de ensayos escritos al calor de esta situación de crisis permanente-. "Ya no constituye el fondo fundante de las experiencias sino una sucesión contingente de procesos de configuración y dispersión".

Las formas de organización creadas por los estados nacionales, como organizaciones obreras, comités de empresa, sindicatos, identidades de clase, terminan de perder el crédito que habían tenido hasta los años sesenta y setenta. Los grupos humanos, sin un discurso social que les preste una identidad, un relato, una historia, se hacen visibles de forma especialmente física, dejando ver lo que Agamben (1998) llama la "nuda vida", la vida en bruto puesta al descubierto una vez más a lo largo de la historia, la vida como testimonio de una supervivencia. El término "descomposición" es la quinta "D" que la investigadora argentina Svampa (2008) añade a la historia de la sociología latinoamericana, tras las " $\mathrm{D}$ " de desarrollo, dependencia, dictadura y democracia. Cuando las democracias se convierten en destino teológico de la Historia en su proceso de autorrealización, la política deja de dialogar con los sectores sociales para ponerse en mano de los profesionales. Las armas se ponen al servicio de las estadísticas y los militares son sustituidos por los asesores. Lo que a las puertas de la II Guerra Mundial escribe Benjamin en el Libro de los pasajes (2005: $\mathrm{N} 13,1)$ acerca del ideal de progreso lo podemos trasladar al concepto de democracia:

tan pronto como el progreso [democracia] se convierte en el rasgo característico de todo el curso de la historia, su concepto aparece en un contexto de hipostatización acrítica en lugar de en uno de planteamiento crítico (Benjamin 2005: N 13, 1). 
$\mathrm{O}$, con las palabras que la artista Angélica Liddell pone en boca de una suerte de animal político del siglo XX:

¿Quién se atreve a llamar genocida a un presidente democrático? / Un tipo corriente que se fotografía con sus perros y sus delfines. / No se puede llamar asesino a un presidente elegido democráticamente (Liddell 2005).

La democracia aparece como la estación de final de viaje, una verdad histórica recubierta de una cierta espiritualidad, por no decir moralismo, un estadio en el que ya solo resta por solventar algunos detalles técnicos para que todo fuera bien. En este sentido iban orientadas las recomendaciones del Fondo Monetario Internacional que terminó llevando a Argentina al quiebre del sistema económico, después de que en 1992 su Presidente, Carlos Menem, fuera felicitado por esta misma institución por el buen comportamiento que estaba teniendo el país. Tras la descomposición social, tras la descomposición crítica (y de la crítica), en manos de los profesionales de la política, de los profesionales de la economía y la cultura -lo que en el ámbito universitario, como expone Svampa, se tradujo igualmente en creciente profesionalización de sus empleados-, vuelven las multitudes sin nombre, sin papeles, ni Estado, los miles de desplazados, inmigrantes y refugiados, masas urbanas y manadas de congresistas sin ideología, cuerpos anónimos en los que lo privado y lo público parecen confundirse al servicio de una verdad previamente construida.

Sin embargo, la idea de "multitud" no es un producto de la globalización. De modo significativo la encontramos en los debates fundacionales del pensamiento político moderno y de la concepción del Estado. Como recuerda Virno (2003), frente a la multitud, Hobbes sitúa al pueblo como dos modos excluyentes de pensar las relaciones sociales. La posibilidad del Estado está vinculada a este último, a la existencia de un grupo con una vocación unitaria que hereda del propio Estado y lo sostiene. A diferencia de Hobbes, Spinoza, convertido desde los años sesenta y setenta en piedra angular del pensamiento de lo social, va a defender esa agrupación de singularidades que es la multitud, los muchos, como un campo de inmanencia que no se deja reducir bajo lo Uno, a la sombra de las instituciones, las representaciones y los mitos de los orígenes. Esto es lo que Deleuze traduce con términos como "multiplicidades" o "manadas": 
En ellas no hay que buscar regímenes de filiación de tipo familiar, ni modos de clasificación y de atribución de tipo estatal o preestatal, ni siquiera instituciones seriales de tipo religioso. [...] el origen de las manadas es completamente distinto que el de las familias y los Estados, y no cesan de minarlos, de perturbarlos desde afuera, con otras formas de contenido, otras formas de expresión (Deleuze/Guattari 1988: 248).

También Sloterdijk en el tercer volumen de las Esferas centrado en la contemporaneidad, que identifica en términos espaciales con la imagen de las espumas o las redes, se detiene en las explicaciones que Occidente ha desarrollado para dar cuenta de las formas de organización social, destacando dos grandes líneas de pensamiento, la sociedad como organismo o la sociedad como contrato. En contraste con estas tesis que tratan de dar cuenta de la utopía social, propone una "Aproximación a las multiplicidades-espacio, que, lamentablemente, se llaman sociedades" (Sloterdijk 2006: 202). La dimensión espacial que guía todo el proyecto de las Esferas vuelve a ponerse de manifiesto como ámbito vital en el que acontece el devenir social, postulando la necesidad de una biosofía que permita pensar el componente sicosomático de la sociedad como acontecimiento. A un imaginario igualmente escénico recurre Latour (2008) para su teoría del actor-red, que sostiene también un modelo inmanentista y dinámico del hecho social.

La multitud es otro modo de estar en la escena pública, de ser público sin dejar de ser singular, de ser naturaleza sin dejar de ser social. Sin embargo, la participación de la multitud de este estadio natural previo pero consustancial al cuerpo político y social, de este devenir-animal al que se refieren Deleuze/Guattari (1988), es lo que para Hobbes la convierte en un peligro para el Estado. Frente al modelo del Estado-Nación la multitud se deja ver como un fenómeno límite que la sociedad civil debe evitar.

También en diálogo con Spinoza, Virno recupera el concepto de "multitud" como un modo de ser característico de la sociedad posfordista, de la época del trabajo inmaterial, del marketing, de los call center, del trabajo social, de las comunicaciones en red -a los que podríamos sumar los congresos, festivales, seminarios y demás eventos que articulan la economía actual de la cultura universitaria-. La desregularización y flexibilización de las formas de contratación laboral, la deslocalización del trabajo y la exigencia de una puesta al día de las habilidades profesionales del trabajador hacen que éste se vea so- 
metido a un proceso de aprendizaje para un trabajo para el que continuamente tiene que estar demostrando su competencia, bajo la amenaza de quedar excluido del sistema. Aquellas historias que cuenta Beck (2002) al comienzo de La sociedad del riesgo global de gente que entraba en una fábrica -o en una universidad, siguiendo con el paralelismo- a los 18 años y se jubilaba en ese mismo sitio, son ya parte del pasado. El trabajo, como la vida, deja de estar garantizado por el Estado.

En esta situación de inestabilidad el individuo recurre a sus capacidades innatas -podríamos decir que biológicas-, aquellas que le proporciona su propia naturaleza, las facultades comunes del género humano, y entre ellas, especialmente, su capacidad mental y lingüística, que en la época del "trabajo inmaterial", una idea ampliamente desarrollada también por Negri, pasan a ser la fuerza central de trabajo.

Pero la multitud tampoco es un concepto maniqueo, carente de ambigüedades, que se oponga frontalmente a la idea de unidad. Participa de una unidad, pero no como destino heredado de una instancia superior, como puede ser el Estado o la Nación, sino como punto de partida previo compartido. Este magma inicial sobre el que se construye le viene dado por esas potencias físicas que Virno denomina "intelecto general", retomando el concepto de Marx.

Dejándose ver como potencia biológica, la multitud abre un espacio que escapa a la construcción social del Estado. Es un espacio público y al mismo tiempo privado, "privado" también en sentido etimológico, del que está privado porque carece de voz pública. A diferencia de las organizaciones legitimadas, la multitud no tiene voz jurídica, no tiene papeles, actúa en una dimensión escénica o en un plano de inmanencia en el que vive en una dinámica constante de concentración y dispersión. En la multitud lo singular y lo colectivo, el individuo y el grupo coexisten en un proceso de individuación que constantemente está teniendo lugar, un proceso que se construye desde esa capacidad compartida, desde esa potencia de hablar, de actuar, de ser y ser en público, es decir, ser político, que confiere una unidad natural a la multitud.

Si retomamos ahora, a la luz de este cuestionamiento de las formas de organización social, la discusión sobre lo literario, veremos que este terreno también se va a ver afectado por este devenir biológico de 
la sociedad en las multitudes. La palabra literaria, es decir, el verbo escrito, carente de cuerpo, viene ligado a una serie de valores que disimulan con creces sus carencias. El declive de la cultura literaria -como apuntábamos al comienzo- se hace coincidir con el declive de Occidente. Como todo mito, el mito de la palabra también es un mito sobre los orígenes. En Lenguaje y silencio Steiner parte de una tesis recurrente en su obra:

¿Estamos saliendo de una era histórica de primacía verbal, del período clásico de la expresión culta, para entrar en una fase de lenguaje caduco, de formas "poslinguísticas" y, acaso, de silencio parcial? (Steiner 2003: 12).

El autor de Después de Babel, recurriendo al mito de la historia, es decir, el mito de la representación escrita, presenta la evolución de Occidente como un proceso de degradación que alcanza su apogeo con el genocidio nazi, que habría supuesto la "crisis de una esperanza racional y humana" (Steiner 2003: 13). Desde este presente se mira con añoranza el espíritu cultural de la Grecia clásica o la Inglaterra de Shakespeare. Este amplísimo arco histórico, en el que parece que solo se salvan estos dos momentos puntuales, la Grecia clásica, una sociedad esclavista, y la Inglaterra de Shakespeare, donde los mismos que iban al teatro acudían en masa a ver peleas de osos, está ligado a una visión mítica de la literatura en relación al proyecto cultural de Occidente. El autor adopta el lenguaje como termómetro de la salud cultural de cada período -"el lenguaje es el misterio que define al hombre"-, pero este lenguaje queda reducido a su expresión escrita, es un lenguaje que carece de cuerpo. Frente a esta concepción inmaterial de la escritura, depositaria de unos fundamentos, igualmente abstractos, que viajan con una aparente ligereza, entre ingenua y perversa, a lo largo de los siglos, Sloterdijk propone algo más físico y concreto como el dolor como termómetro de la realidad, abogando por una ética fisionómica, una ética somática, de la que nos habla también Goytisolo, capaz de pensar la realidad política a partir del cuerpo y la representación (de la historia) a partir de los acontecimientos.

Las condiciones de vida impuestas por un sistema económico que se maneja a nivel mundial, dejando al descubierto necesidades locales, ha sacado a la luz estas multitudes como fuerza física cargada de una extraña dimensión social. Ésta es la fuerza "biopolítica", utilizando el concepto introducido por Foucault a finales de los setenta, que luego 
Agamben desarrolla en los noventa desde un horizonte histórico más próximo.

Si Foucault (2007), ya en los años sesenta, hablaba de cárceles y hospitales para la época del Gran Encerramiento, Agamben (1998) propone el "campo de concentración" y el "estado de excepción" como paradigmas políticos del siglo XX. Si las cárceles estaban todavía ligadas a un discurso en torno a los derechos sociales y políticos, los campos de concentración solo admiten un discurso sobre los derechos humanos, siguiendo con este progresivo solapamiento entre "nuda vida" y espacio político. Este estado de excepción, y con él las multitudes, se han hecho cada vez más presentes para dejar ver lo que solo está incluido en forma de exclusión, la vida al margen de su condición política, la multitud como límite de lo social. De los campos de concentración no hay vuelta atrás, ni de los estados de excepción, como tampoco hay vuelta atrás del desencanto de los Estados soberanos o del proyecto humanista de la literatura.

Lo que corresponde, según Agamben, es deshacer las articulaciones, romper los puentes sobre los que se construyen los relatos que han entrelazado dentro de un continuum derecho y vida, literatura y cuerpo, como dispositivos que terminan ocultando lo que excluyen, el derecho a la vida o las razones del cuerpo; liberar la palabra, al igual que la política, según la propuesta de Badiou (2007: 13), "de la tiranía de la historia, para restituirla al acontecimiento", pensarla como un lugar de corte, como quería también Goytisolo, que entra y sale de la historia para poder rescatarla desde un presente, desde un devenir cuerpo vivo, performativo y espacial, y no sobre la asunción de un poder heredado.

Porque esta inquietante potencia biológica es también y sobre todo una capacidad de actuar, a la que se refiere Juan Goytisolo en relación a Juan sin Tierra, obra que cierra aquella trilogía de la liberación con la que el autor anuncia en los años setenta su programa definitivo de ruptura con la Historia oficial, en este caso, la del Estado español, pero también con ello la ruptura con la historia cultural y finalmente literaria de dicho Estado. El relato de esta ruptura fue articulado como un acto de traición a un sistema político sostenido por unos valores y unos mitos de los que se trataba de desprender, y al mismo tiempo de una gramática narrativa que se estaba transgrediendo. 
Algunos capítulos de Juan sin Tierra - dice Goytisolo- no son sino una parábola sobre las pulsiones motrices que empujan al hombre a la acción: anhelo de comunión física, fisiológica, anatómica del narrador con los parias y los metecos, esto es, los negros y árabes perseguidos y negados en nuestras sociedades represivas (Goytisolo/Ríos 1977: 18),

un impulso de naturaleza biológica que el mismo escritor apunta como motivación primera y última de su trabajo literario, entendido éste como un tipo de acción/intervención en un sentido casi performativo, es decir, físico (Cornago 2005).

No es de extrañar que, desde un medio eminentemente físico como el teatro, se haya retomado esta discusión a lo largo de los años noventa, cuestionando nuevamente los mitos que entrelazan bajo un mismo relato político individuo y sociedad, cuerpo y palabra, historia y naturaleza. Frente a los imperativos de la historia, del relato dramático o del relato de la política, la escena se muestra como un acto de afirmación física, que es la afirmación también de una capacidad, de una posibilidad de actuar. Lo primero que un actor -no sólo teatral, sino también político, social o religioso- dice con su cuerpo cuando entra en escena es un yo-actúo, es decir, un yo-estoy-actuando, porque tengo esta capacidad, la exhibición de una capacidad. "Yo-actúo" quiere decir "yo-puedo-actuar". Y esto es lo que se trata de hacer visible por medio del énfasis de las acciones a través de su dimensión performativa, cuando son presentadas como tales acciones y no como parte de una representación unitaria que dé sentido al conjunto.

No es un azar que nombres clásicos que discutieron la formación del Estado y la naturaleza social del individuo, como Montaigne, Rousseau, Diderot, u otros más próximos como Sloterdijk, hayan vuelto a aparecer en la escena contemporánea comprometida con un discurso físico. Si Rodrigo García (2005) convierte al autor de las Esferas en personaje de su obra Prefiero que me quite el sueño Goya a que lo haga cualquier hijo de puta, Angélica Liddell plantea un diálogo cara a cara entre el autor de El contrato social y Diderot, cuya obra El sobrino de Rameau es punto de partida de Perro muerto en tintorería: los muertos (Liddell 2007). En ambos casos, por citar únicamente algunas de las líneas más coherentes y radicales de creación escénica vinculadas al panorama español, la relación del individuo con la sociedad, así como la relación entre la palabra y el cuerpo, aún recibien- 
do tratamientos muy distintos, constituye un campo de conflicto central en la obra de ambos autores.

El director y dramaturgo -o mejor deberíamos decir en unos términos posdictatoriales: creador escénico y escritor- Rodrigo García ha llevado a cabo un trabajo con la palabra al mismo tiempo que con los cuerpos, tratando de delimitar con claridad los espacios específicos de uno y otro, los espacios de la palabra y los espacios del cuerpo, de manera casi paralela y sin que el uno interfiera o se confunda con el otro. En sus últimas obras la mayor parte del texto es proyectada en grandes caracteres sobre una pantalla situada al fondo del escenario, mientras que en la escena se despliega un universo físico que no tiene que ver con el plano referencial de los textos.

El cruce entre una reflexión desde el cuerpo, en términos muchas veces fisiológicos, y un panorama social que solo se deja entrever como interrogante, vuelve a conducir al tema de las multitudes como la otra dimensión -física- de la organización social.

No expresamos ideas -se lee en Versus (2008)-. Desplazamos química. La formación de un pensamiento no son las palabras. Un pensamiento se cristaliza en asuntos tangibles, como el crecimiento de las uñas o el cáncer en las células.

Aunque con recursos formales distintos, tanto en García como en Liddell, desde una reivindicación radical del yo, se levanta un interrogante sobre las posibilidades de las formas de organización social. Frente al pacto Liddell reivindica el cuerpo, frente al consenso la pasión, desde una posición declaradamente antisocial, que comparte también con García. Sin embargo, ese horizonte social no deja de aparecer aunque sea como término de exclusión y espacio de conflicto, el punto imposible de llegada al que se enfrenta el individuo desde su condición biológica:

Mi punto de vista, como el del mono, es totalmente antisocial, pasional. Mi punto de vista incluye las definiciones de Pasión: “acción de padecer; cualquier perturbación o afecto desordenado del ánimo; en medicina, afecto o dolor sensible de alguna de las partes del cuerpo enfermo; inclinación o afición vehemente a una cosa". Contra una sociedad ruin que aspira a cualquier tipo de poder, que consume poder compulsivamente, me declaro apasionada. Mi obra, que es una acción más de mi vida, sobrevive apasionada (Liddell 2003: 104).

Los textos de Rodrigo García hablan de experiencias personales, contadas desde un yo omnipresente, a veces son anécdotas o lugares inti- 
mistas, y otras muchas se trata de pasajes de crítica social, denuncia del capitalismo global y la sociedad de consumo. Mientras se proyectan o se dicen estos textos, la escena está ocupada por los cuerpos y las acciones, los materiales y la naturaleza en bruto. Dos universos que chocan entre sí y que son recibidos por el público a través de canales distintos: uno es de tipo intelectual y requiere un proceso de abstracción, como es la escritura; el otro es físico y sensorial, y aporta el sentido del acontecimiento.

En Cruda, vuelta y vuelta, en su punto y chamuscada, producida por el Festival de Salamanca y el Festival de Avignon en 2006, el creador hispano-argentino lleva a escena a un grupo de murga. Estos jóvenes, procedentes de una villa miseria de Buenos Aires, ciudad en la que nació también García, construyen un mundo físico, nocturno y material, cargado de energía, que deja ver la base natural sobre la que crecen las multitudes, las manadas -como diría Deleuze-, un devenir animal, nocturno y débil convertido en potencia de vida, en capacidad de actuación.

En escena, un sólo actor profesional, Juan Loriente, que al final de la obra dice el único texto de la obra -aparte de los relatos en primera persona de los integrantes de la murga, que no forman parte del texto dramático- que no va a ser proyectado. Es un largo monólogo en el que se propone la refundación del mundo, una vez constatado el fracaso de las democracias, el fracaso del hombre como sociedad. Para esta refundación se toma una medida natural, el tiempo que una vaca tarda en olvidar un sentimiento. La vaca del relato enloquece cuando descubre que se habían llevado a sus terneros. El arrebato pasará en unos dos días, contestan los dueños del establo. Entonces se propone esa medida como base para un nuevo mundo en el que nada dure más de dos días, en el que todo tenga que volver a empezar cada dos días, emociones y sentimientos, sistemas filosóficos y sistemas políticos, lazos de amistad y formas de organización social. Y esto es propuesto como la base para una nueva ética, una Gran Ética, como se dice en el texto, que no anda lejos de aquella ética somática de Sloterdijk. En este devenir-animal al hombre se le da "el mismo atributo / que a los perros, los faisanes, los atunes y los búhos / la exaltación y el arrebato", pero no el tiempo para desarrollar un pensamiento político, "aunque sí que se podían desarrollar infinitos sistemas filosóficos inacabados". 
Exaltación y arrebato pueden servir también para calificar el universo de Angélica Liddell, en el que el componente físico y emocional del yo es presentado como defensa última contra el Estado. En Perro muerto, estrenada en el Teatro Valle-Inclán, del Centro Dramático Nacional de Madrid en 2007, se presenta un submundo en una época en la que el Estado ha aniquilado definitivamente al enemigo en nombre de la Seguridad. La pregunta es cómo sigue el hombre haciéndose cargo de sus miedos y deseos, de sus pasiones personales, como sigue haciéndose cargo de su propio cuerpo. Como explica la autora acerca de los personajes:

Estaban acostumbrados a temer a un enemigo común y ahora, una vez aniquilado el enemigo común, se temen a sí mismos, no saben cómo gestionar sus deseos. La perfección del nuevo sistema, fundamentada también en la represión moral, despierta en los cuatro protagonistas una necesidad imperiosa de error, de catástrofe, demandan crímenes, ya no pueden vivir sin horrorizarse, reclaman lo corporal con violencia y solo encuentran alivio a su angustia en el sexo, en lo absolutamente concreto (Liddell 2007: 9).

El "estado de excepción", convertido en norma de la vida política internacional, deja ver la nuda vida como sustrato sobre el que se levanta el Estado soberano, aquello que está incluido sólo en modo de exclusión. Igual que el soberano es aquel que está dentro y fuera de la ley, quien la funda a la vez que se convierte en su excepción, según la definición de Schmitt -"Yo, el soberano, que estoy fuera de la ley, declaro que no hay un afuera de la ley"-, recogida por Agamben (1998: 27), la nuda vida es también aquello que está dentro y fuera de la política, como la multitud es lo que constituye lo social a la vez que se muestra como su amenaza. Amor y política, cuerpo y Estado, biología y totalitarismo son términos dispares que la tradición occidental ha tratado de subsumir dentro del relato de la utopía a la que apunta el mito de los Estados-Nación. Ambos componentes se hacen ahora visibles como las dos caras de un mismo mecanismo de poder. En El año de Ricardo (Liddell 2005), la obra que precedió a Perro muerto, el personaje central, una especie de monstruo político interpretado por la propia autora, personificación de dictadores y gobernantes del siglo $\mathrm{XX}$, insiste en este componente biológico del poder a lo largo de las casi dos horas que dura este monólogo, a un ritmo trepidante que no cesa durante todo el espectáculo. Finalmente, la vehemencia física de la multitud, la dimensión emocional de la manada, convertida en 
chusma, se proyecta en el comportamiento, aparentemente ideológico, de quienes dirigen las organizaciones sociales. Tras varios siglos tratando de transformar las multitudes en organizaciones, éstas vuelven a aflorar, en estado bruto, en su devenir animal, paria, chusma, para poner de manifiesto la condición biopolítica sobre la que se asienta el poder totalitario:

¡Por supuesto que puedo matar en nombre de la ideología!

Al fin y al cabo eso es lo que nos debe diferenciar de la chusma.

Nosotros matamos por ideología.

Y ellos matan por pasión.

A sus mujeres, a sus hermanos, a sus hijos...

La chusma mata por pasión.

De eso se trata.

De hacerles creer que matamos por una cuestión de ideas

y no por una cuestión de pasión.

La situación emocional de las masas.

$[\ldots]$

Fundir tres conceptos,

la Masa, el Estado y la Nación (Liddell 2005).

\section{Bibliografía}

Adorno, Theodor W. (1975): Dialéctica negativa. Madrid: Taurus/Cuadernos para el Diálogo.

Agamben, Giorgio (1998): Homo sacer. El poder soberano y la nuda vida I. Valencia: Pre-Textos.

Anderson, Benedict (1993): Las comunidades imaginarias. México, D.F.: Fondo de Cultura Económica.

Badiou, Alain (2007): ¿Se puede pensar la política? Buenos Aires: Nueva Visión.

Bauman, Zygmunt (2005): Modernidad líquida. Buenos Aires: Fondo de Cultura Económica.

Beck, Ulrich (2002): La sociedad del riesgo global. Amok, violencia, guerra. Madrid: Siglo XXI.

Benjamin, Walter (2005): Libro de los pasajes. Madrid: Akal.

Cornago, Óscar (2005): Resistir en la era de los medios. Estrategias performativas en literatura, teatro, cine y televisión. Madrid/Frankfurt am Main: Iberoamericana/ Vervuert.

Deleuze, Gilles/Guattari, Félix (1988): Mil mesetas. Capitalismo y esquizofrenia. Valencia: Pre-Textos.

Foucault, Michel (1997): Historia de la sexualidad 1. La voluntad de saber. México, D.F.: Siglo XXI. 
- (2007): Historia de la locura en la época clásica. México, D.F.: Fondo de Cultura Económica.

García, Rodrigo (2005): Prefiero que me quite el sueño Goya a que lo haga cualquier hijo de puta. Madrid: Aflera.

- (2008): Versus. Madrid: Aflera.

Goytisolo, Juan (1991): La cuarentena. Madrid: Mondadori.

- (1993): La saga de los Marx. Madrid: Mondadori.

Goytisolo, Juan/Ríos, Julián (1977): "Desde Juan sin Tierra". En: Espiral/Revista: Juan sin Tierra (Número monográfico), 2, pp. 7-25.

Latour, Bruno (2008): Reensamblar lo social. Una introducción a la teoría del actorred. Buenos Aires: Manantial.

Lewkowicz, Ignacio (2004): Pensar sin Estado. La subjetividad en la era de la fluidez. Buenos Aires: Paidós.

Liddell, Angélica (2003): "El mono que aprieta los testículos de Pasolini”. En: Primer Acto, 300, pp. 104-108.

- (2005): El año de Ricardo. Cuenca: Archivo Virtual de las Artes Escénicas (<www.artesescenicas.uclm.es/archivos_subidos/textos/240/ angelicaliddell_ricardo.pdf $>$; 14.11.2010).

- (2007): Perro muerto en tintorería: los fuertes. Cuenca: Archivo Virtual de las Artes Escénicas (<www.artesescenicas.uclm.es/archivos_subidos/textos/241/ Angelica $\% 20$ Liddell\%20-\%20Perro\%20muerto\%20en\%20tintoreria.pdf $>$; 14.11.2010).

Negri, Antonio (2007): Goodbye Mr. Socialism. La crisis de la izquierda y los nuevos movimientos revolucionarios. Conversaciones con Raf Valvola Scelsi. Barcelona: Paidós.

Negri, Antonio/Cocco, Giuseppe (2006): Global. Biopoder y luchas en una América latina globalizada. Buenos Aires: Paidós.

Sloterdijk, Peter (2000): Normas para el parque humano. Una respuesta a la Carta sobre el humanismo de Heidegger. Madrid: Siruela.

- (2006): Esferas III. Espumas. Esferología plural. Madrid: Siruela.

Steiner, George (2003): Lenguaje y silencio. Ensayos sobre la literatura, el lenguaje y lo inhumano. Barcelona: Gedisa.

Svampa, Maristella (2008): Cambio de época. Movimientos sociales y poder político. Buenos Aires: Siglo XXI.

Todorov, Tzvetan (1993): Frente al límite. México, D.F.: Siglo XXI.

- (1995): La vida en común. Ensayo de antropología general. Madrid: Taurus.

Virno, Paolo (2003): Gramática de la multitud. Para un análisis de las formas de vida contemporáneas. Madrid: Traficantes de Sueños. 